\title{
Study on sterile and sub-sterile conditions in cow and buffalo in Mawana tehsil of district Meerut of Uttar Pradesh
}

\author{
DEVESH GUPTA
}

\begin{abstract}
In the present survey 5 main and 5 sub A.I. centres of Mawana tehsil of district Meerut were selected. Sterile and sub sterile condition data were recorded during one year (January to December). The major cause found was nutritional in both cows and buffaloes. It is suggested to provide better nutritional and Managemental condition for controlling the sterility and adopt prophylaxis and curative measures control the genetic sterility.
\end{abstract}

KEY WORDS : Cow, Buffalo, A.I. centre, Sterility, Causes

HOW TO CITE THIS PAPER : Gupta, Devesh (2015). Study on sterile and sub-sterile conditions in cow and buffalo in Mawana tehsil of district Meerut of Uttar Pradesh. Res. J. Animal Hus. \& Dairy Sci., 6(1) : 83-84. 